\title{
PENGATURAN TENTANG HAK ASASI MANUSIA BERDASARKAN UNDANG-UNDANG DASAR 1945 SEBELUM DAN SETELAH AMANDEMEN*
}

\author{
Oleh : \\ Tenang Haryanto, Johannes Suhardjana, A. Komari, \\ Muhammad Fauzan, dan Manunggal Kusuma Wardaya \\ Fakultas Hukum Universitas Jenderal Soedirman Purwokerto
}

\begin{abstract}
The end of the government of Orde Baru that tends to be more authoritharian has emerged the transformation almost in all government hierarchy. The most important transformation is in the material contains or substantive of 1945 constitution, whether material that has been erased, revised or new material. Material contain of the 1945 constitution is the result of the amendment such as the Human Right. The regulation about human right before amendment 1945 constitution regulated as right and duty of the republic citizen in Indonesia that contains the values of human right and regulated in the article 27 to article 34. The regulation of human right after amendment of 1945 constitution regulated in article $28 \mathrm{~A}$ to 28J. The regulation about the human right based on the Law Number 39 Year 1999 concerning the Human Right. It explain there is no right in Indonesia that has the absolute power and unlimited. Human Right is not the right that has the absolute characteristic. In the implementation, its limited by the right, morale, security and order of other people. Because of that, in the human right also known the existence of human right duty. Moreover, the implementation of the human right has been regulated in the 1945 Constitution.
\end{abstract}

Kata Kunci : Hak Asasi manusia, Amandemen UUD 1945

\section{A. Pendahuluan}

Hak asasi adalah hak yang dimiliki manusia yang telah diperoleh dan dibawanya bersamaan dengan kelahiran atau kehadirannya di dalam kehidupan masya-rakat. Dianggap bahwa beberapa hak itu dimilikinya tanpa perbedaan atas dasar bangsa, ras, agama, atau kelamin, dan karena itu bersifat asasi serta universal. Dasar dari semua hak asasi ialah bahwa manusia harus memperoleh kesempatan untuk berkembeng sesuai dengan bakat dan cita-citanya. Setelah dunia mengalami perang yang melibatkan hampir seluruh dunia dan dimana hak-hak asasi diinjak-injak, timbul keinginan untuk merumuskan hak-hak asasi manusia itu dalam suatu naskah internasional. Usaha ini pada tahun 1948 berhasil dengan diterimanya Universal Declaration of Human Rights (Pernyataan Sedunia tentang Hak-Hak

\footnotetext{
* Artikel ini merupakan artikel hasil penelitian dari penelitian yang dilakukan dengan Anggaran DIPA Unsoed 2008
}

Asasi Manusia) oleh negara-negara yang tergabung dalam Perserikatan Bangsa-Bangsa. ${ }^{1}$

Di Indonesia, seperti juga di negaranegara yang lain, juga telah mencantumkan beberapa hak asasi di dalam undang-undang dasarnya baik dalam Undang-Undang Dasar 1945, Konstitusi RIS, maupun Undang-Undang dasar Sementara 1950. Hak-hak asasi yang tercantum dalam Undang-Undang Dasar 195 (sebelum amandemen)tidak termuat dalam suatu piagam yang terpisah tetapi tersebar dalam beberapa pasal, terutama Pasal 27 sampai Pasal $34 .^{2}$

Hak-hak asasi dimuat terbatas jumlahnyadan dirumuskan secara singkat, hal ini tidak mengherankan, mengingat bahwa naskah ini disusun pada akhir masa pendudukan

\footnotetext{
Miriam Budiardjo, 1980, Dasar-Dasar Ilmu Politik, Jakarta: Gramedia, hlm.120 Lihat juga Jimly Asshiddiqie., 2005, Konstitusi dan Konstitusionalisme Indonesia, Jakarta: Konstitusi Press, hlm. 152-162

2 Safroedin Bahar, 1996, Hak Asasi Manusia, Analisis Komnas HAM dan Jajaran Hankam/ABRI, Jakarta: Pustaka Sinar Harapan, hlm.2
} 
bala tentara Jepang dan dalam suasana yang mendesak. ${ }^{3}$ Hal tersebut mengakibatkan tidak cukup waktu untuk membicarakan hak asasi secara mendalam sekali, sedangkan kehadiran tentara Jepang di Indonesia tidak menciptakan iklim yang menguntungkan untuk merumuskan hak-hak asasi secara lengkap.

Selain daripada itu, diantara tokoh-tokoh masyarakat juga berbeda pendapat mengenai peranan hak-hak asasi di dalam negara demokratis. Para tokoh tersebut diantaranya adalah Ir. Sukarno, dan Drs. Moh. Hatta yang masing-masing mempunyai argumen masingmasing bagi perlu tidaknya pengaturan hak-hak asasi dalam undang-undang dasar. Oleh karena itu, dapat dimengerti mengapa hak-hak asasi tidak lengkap dimuat dalam Undang-Undang Dasar 1945 (sebelum amandemen), karena Undang-Undang Dasar 1945 tersebut dibuat beberapa tahun sebelum pernyataan hak-hak asasi dideklarasikan oleh PBB pada tanggal 10 Desember $1948 .^{4}$

Perkembangan sejarah ketatanegaraan menghendaki, bahwa dengan tumbangnya rezim pemerintahan Orde Baru yang cenderung otoriter telah mengakibatkan perubahan hampir seluruh tatanan bernegara. Perubahan yang sangat penting diantaranya adalah terhadap materi muatan atau substansi Undang-Undang Dasar 1945, baik materi yang dihapus, direvisi, maupun ditambah materi yang betul-betul baru. Materi muatan Undang-Undang Dasar 1945 hasil amandemen yang merupakan materi baru, diantaranya adalah tentang Pemilihan Umum, Mahkamah Konstitusi, Dewan Perwakilan Daerah, Pertahanan dan Keamanan, serta Hak Asasi Manusia.

\section{B. Perumusan Masalah}

Berdasarkan pendahuluan di atas, maka dapat dirumuskan permasalahan berupa bagaimanakah pengaturan tentang hak asasi manusia

\footnotetext{
3 Masyhur Effendi, 1994, Haka Asasi Manusia dalam Hukum Nasional dan Internasional, Jakarta: Ghalia Indonesia, $\mathrm{hlm} .19$

4 Ibid, hlm.127
}

sebelum dan sesudah amandemen UndangUndang Dasar 1945?

\section{Metode Penelitian}

Metode pendekatan yang digunakan dalam penelitian ini adalah yuridis normatif dengan fokus pada pendekatan perundangundangan (statute approach). Spesifikasi penelitian ini adalah deskritif denga sumber data utama berupa data sekunder. Data sekunder berupa peraturan perundangundangan, buku dan sumber lain diinventarisir dan dipelajari, kemudian dicatat berdasarkan relevansinya dengan obyek permasalahan. Data yang diperoleh kemudian dianalisis dengan menggunakan analisis kualitatif.

\section{Pembahasan}

Hukum dasar tertulis sebagai dasar bagi penyelenggaraan kenegaraan di Indonesia adalah Undang-Undang Dasar 1945 yang mencakup Pembukaan dan Batang Tubuh. Mengenai hal ini, Mukthi Fadjar berpendapat sebagai berikut: Undang-Undang Dasar 1945 adalah hukum dasar tertulis yang berlaku di Indonesia yang meliputi atau mencakup Pembukaan dan Batang Tubuh Undang-Undang Dasar 1945. Apabila dikaji kedua komponen tersebut dengan pendekatan filosofis (ontologis), historis-sosiologis, sistematis dan yuridis-fungsional, menunjukkan adanya komitmen kemanusiaan yang tinggi dari bangs Indonesia meskipun belum diidealisasi dan disistematisasi secara lengkap dalam daftar hak-hak asasi manusia seper-ti halnya piagam HAM sedunia beserta konvenannya. Hal ini bisa dimengerti karena Undang-Undang Dasar 1945 kehadirannya lebih dahulu daripada deklarasi hak asasi manusia. ${ }^{5}$

Pengaturan hak asasi manusia berdasarkan Undang-Undang Dasar 1945 dapat dilihat dari ketentuan dalam Pembukaan dan pasal-pasal dalam Batang Tubuh setelah amandemen.

\footnotetext{
5 Mukthi Fadjar, 2004, Tipe Negara Hukum, Malang: Bayumedia Publishing, hlm. 90. Lihat juga Padmo Wahjono, 1983, Indonesia Negara Berdasar Hukum, Jakarta: Ghalia Indonesia, hlm.54
} 
Mencermati hal di atas, pemikiran HAM sejak awal pergerakan kemerdekaan hingga saat ini mendapat pengakuan dalam bentuk hukum tertulis yang dituangkan dalam berbagai peraturan perundang-undangan yang berpuncak pada konstitusi sebagai peraturan perundangundangan tertinggi di Indonesia. Hal ini ternyata dalam sejarah perjalanan bangsa Indonesia yang telah melewati kurun waktu berlakunya tiga konstitusi, yakni UUD 1945, Konstitusi RIS 1949 dan UUDS 1950, yang kesemuanya memuat ketentuan-ketentuan HAM di bidang sipil, politik, ekonomi, sosial dan budaya.

Meskipun UUD 1945 memuat ketentuanketentuan tentang HAM yang mencakup bidang bidang sipil, politik, ekonomi, sosial dan budaya, namun pengaturan itu dianggap belum rinci. Oleh karena itu, kemudian timbul pertanyaan dalam bentuk hukum apakah rincian HAM itu harus ditetapkan.

Ismail Suny, sebagaimana dikutip oleh Bagir Manan, berpendapat bahwa terdapat tiga kemungkinan bentuk hukum yang dapat menampung rincian HAM itu, yaitu Pertama, menjadikannya bagian integral dari UUD 1945, yaitu dengan cara melakukan amandemenamandemen pada UUD 1945, sebagai yang ditempuh dengan Piagam Hak-Hak Warganegara (The Bill of Rights), yang merupakan amandemen I-X pada Konstitusi Amerika Serikat. Cara semacam ini akan menjamin tetap terpeliharanya UUD 1945 sebagai naskah historis dimana dalam the body of the constitution tidak diadakan perubahan-perubahan, tetapi hanya tambahan-tambahan. Prosedurnya menurut hukum konstitusi diatur pada Pasal 37.

Kedua, menetapkan dalam Ketetapan Majelis Permusyawaratan Rakyat. Keberatannya, suatu Ketetapan Majelis Permusyawaratan Rakyat pada umumnya tidak mengatur ancaman hukuman bagi pelanggarnyadalam precise detail, tetapi hanya garis-garis besar haluan negara, sekedar "a declaration of general principles", tanpa akibat hukum sama sekali. Ketiga, mengundangkannya dalam suatu un-- dang-undang berikut sanksi hukuman terhadap pelanggar-nya. ${ }^{6}$ Dari ketiga bentuk hukum di atas, tampaknya ketiga-tiganya dipergunakan olehpemerintah Indonesia dalam menguraikan rincian HAM.

UUD 1945 yang pada awalnya hanya memuat 6 pasal yang mengatur tentang HAM, kemudian mengalami perubahan-perubahan yang sangat signifikan yang kemudian dituangkan dalam Perubahan Kedua UUD 1945 pada Bulan Agustus Tahun 2000. Sebenarnya, sebelum Perubahan Kedua dilakukan, telah terdapat beberapa peraturan perundang-undangan yang dapat dikatakan sebagai pembuka terjadinya perubahan. Ketentuan itu antara lain Ketetapan MPR Nomor XVII/MPR/1998 Tentang Hak Asasi Manusia, Ketetapan MPR Nomor IV/MPR/1999 Tentang GBHN, serta UndangUndang Nomor 39 Tahun 1999 Tentang Hak Asasi Manusia.

Melalui Ketetapan MPR Nomor IV/MPR/ 1999 Tentang GBHN, MPR telah menetapkan politik hukum yang harus dilaksanakan oleh pihak eksekutif yang mencakup substansi hukum, struktur hukum dan budaya hukum. Kesemuanya tercantum dalam visi, misi dan arah kebijakan. Berkaitan dengan substansi hukum, Ketetapan MPR tersebut menggariskan bahwa penataan sistem hukum nasional dilakukan secara menyeluruh dan terpadu dengan menghormati hukum agama dan hukum adat serta memperbaharui perundang-undangan yang dinilai diskriminatif. Selain itu, pemerintah didorong untuk segera melakukan retifikasi konvensi internasional terutama di bidang HAM dalam bentuk Undang-undang. Dengan kata lain, Ketetapan ini telah menegaskan bahwa jenis peraturan perundang-undangan untuk retifikasi adalah Undang-undang, dan tidak boleh dalam jenis lain, misalnya Keputusan Presiden.

Kewajiban yang harus dilaksanakan oleh pemerintah berkaitan denganbidang struktur hukum adalah penegakan hukum untuk men-

\footnotetext{
6 Bagir Manan, 2001, Perkembangan Pemikiran dan Pengaturan Hak Asasi Manusia di Indonesia, Bandung: Alumni, hlm. 81
} 
jamin HAM serta penyelesaian proses peradilan terhadap pelanggaran HAM yang belum ditangani secara tuntas. Sedangkan dalam kaitan dengan budaya hukum, pemerintah wajib berperan aktif untuk meningkatkan pemahaman dan penyadaran HAM dalam seluruh aspek kehidupan.

Pada pembahasan Rancangan UUD yang dilakukan oleh PPKI pada tanggal 18 Agustus 1945 Soekarno sebagai Ketua Panitia Perancang UUD telah menyatakan kehendak bahwa dikemudian hari akan dibuat suatu UUD baru, karena UUD yang dibuat adalah UUD sementara atau yang ia namakan sebagai UUD kilat. Dari hal itu, tampak kearifan dari pembentuk UUD 1945 yang menyadari bahwa UUD tersebut tidak lengkap sehingga membuka peluang untuk diadakan perubahan atau penyempurnaan yang kemudian diatur dalam Pasal 37.

Salah satu ketidakberhasilan UndangUndang Dasar 1945 sebagai dasar pelaksana prinsip-prinsip demokrasi dan negara berdasarkan atas hukum antara lain disebabkan adanya kekosongan materi muatan, misalnya tentang HAM. Wacana tentang perlunya HAM dimasukkan ke dalam UUD berkembang ketika kesadaran akan pentingnya jaminan perlindungan HAM semakin meningkat menyusul tumbangnya rejim otoriter. Pandangan kritis terhadap UUD 1945, yang dahulu ditabukan, sejak masa reformasi membenarkan pendapat bahwa UUD tersebut tidak secara eksplisit mengatur masalah HAM. Bahkan beberapa pakar secara tegas menyetakan bahwa Undang-Undang Dasar 1945tidak mengenal HAM karena dirumuskan sebelum adanya Deklarasi Universal HAM.

Hasil amandemen UUD 1945 memberikan suatu titik terang bahwa Indonesia semakin memperhatikan dan menjunjung nilai-nilai Hak Asasi Manusia (HAM) yang selama ini kurang memperoleh perhatian dari Pemerintah. Amandemen kedua bahkan telah menelurkan satu Bab khusus mengenai Hak Asasi Manusia yaitu Bab XA. Apabila ditelaah menggunakan perbandingan konstitusi dengan negara-negara lain, hal ini merupakan prestasi tersendiri bagi perjuangan HAM di Indonesia, sebab tidak banyak negara di dunia yang memasukkan bagian khusus dan tersendiri mengenai HAM dalam konstitusinya.

Rujukan yang melatarbelakangi perumusan Bab XA (Hak Asasi Manusia) UUD 1945 adalah Ketetapan MPR Nomor XVII/MPR/1998. Ketetapan MPR tersebut kemudian melahirkan UndangUndang Nomor 39 Tahun 1999 Tentang Hak Asasi Manusia. Semangat keduanya, baik itu Ketetapan MPR Nomor XVII/MPR/1998, maupun Undang-Undang Nomor 39 Tahun 1999 adalah sama yakni menganut pendirian bahwa hak asasi manusia bukan tanpa batas. Dikatakan pula bahwa semangat yang sama juga terdapat dalam pengaturan tentang hak asasi dalam UUD 1945, yaitu bahwa hak asasi manusia bukanlah sebebas-bebasnya melainkan dimungkinkan untuk dibatasi sejauh pembatasan itu ditetapkan dengan undang-undang. Semangat inilah yang melahirkan Pasal 28 J UUD 1945. Pembatasan sebagaimana tertuang dalam Pasal $28 \mathrm{~J}$ itu mencakup sejak Pasal 28 A sampai dengan Pasal 28 I UUD 1945. Oleh karenanya, hal yang perlu ditekankan di sini bahwa hak-hak asasi manusia yang diatur dalam UUD 1945 tidak ada yang bersifa mutlak, termasuk hak asasi yang diatur dalam Pasal 28 I ayat (1) UUD 1945.

Jika ditarik dari perspektif original intent pembentuk UUD 1945, bahwa seluruh hak asasi manusia yang tercantum dalam Bab XA UUD 1945 keberlakuannya dapat dibatasi. Original intent pembentuk UUD 1945 yang menyatakan bahwa hak asasi manusia dapat dibatasi juga diperkuat oleh penempatan Pasal $28 \mathrm{~J}$ sebagai pasal penutup dari seluruh ketentuan yang mengatur tentang hak asasi manusia dalam Bab XA UUD 1945 tersebut. Secara penafsiran sistematis (sistematische interpretatie), hak asasi manusia yang diatur dalam Pasal 28 A sampai dengan Pasal 28 I UUD 1945 tunduk pada pembatasan yang diatur dalam Pasal $28 \mathrm{~J}$ UUD 1945.

Sistematika pengaturan mengenai hak asasi manusia dalam UUD 1945 ini sejalan pula dengan sistematika pengaturan dalam Universal Declaration of Human Rights yang juga menempatkan pasal tentang pembatasan hak 
asasi manusia sebagai pasal penutup, yaitu Pasal 29 ayat (2) yang menegaskan :

In the exercise of his rights and freedoms, everyone shallbe subject only to such limitations as are determined by law solely for the purpose of securing due recognition and respect for the rights and freedoms of others and of meeting the just requirements of morality, public order, and the general welfare in a democratic society.

Apabila dilihat dari sejarah perkembangan konstitualisme Indonesia, sebagaimana tercermin dalam konstitusi-konstitusi yang pernah berlaku, yakni UUD 1945 sebelum amandemen, Konstitusi RIS 1949, UUDS 1950, dan UUD 1945 sesudah amandemen, tampak adanya kecenderungan untuk tidak memutlakkan hak asasi manusia, dalam arti bahwa dalam hal-hal tertentu, atas perintah konstitusi, hak asasi manusia dapat dibatasi oleh suatu undangundang. Adapun penjelasannya adalah :

1. UUD 1945 sebelum Perubahan bahkan tidak memuat secara eksplisit dan lengkap pengaturan tentang hak asasi manusia, termasuk tentang hak untuk hidup, meskipun dalam Alinea ke-4 memuat apa yang kemudian disebut sebagai Pancasila yang salah satunya adalah sila "Kemanusiaan yang adil dan beradab".

2. Pasal 32 ayat (1) Konstitusi RIS 1949 memuat ketentuan tentang pembatasan "Hakhak dan Kebebasan-kebebasan Dasar Manusia" sebagai berikut : "Peraturan-peraturan undang-undang tentang melakukan hak-hak kebebasan-kebebasanyang diterangkan dalam bagian ini, jika perlu, akan menetapkan batas-batas hak-hak dan kebebasan itu, akan tetapi hanyalah semata-mata untuk menjamin pengakuan dan penghormatan yang tak boleh tiada terhadap hak=hak serta kebebasan-kebebasan orang lain, dan untuk memenuhi syarat-syarat yang adil untuk ketenteraman, kesusilaan, dan kesejahteraan umum dalam suatu persekutuan yang demokrasi".

3. Pasal 33 UUDS 1950 juga membatasi HAM (Hak-hak dan Kebebasan-kebebasan Dasar
Manusia) sebagai berikut : "Melakukan hakhak dan kebebasan-kebebasan yang diterangkan dalam bagian ini hanya dapat dibatasi dengan peraturan-peraturan undang-undang semata-mata untuk menjamin pengakuan dan penghormatan yang tak boleh tiada terhadap hak-hak serta kebebasan-kebebasan orang lain, dan untuk memenuhi syarat-syarat yang adil untuk ketenteraman, kesusilaan, dan kesejahteraan dalam suatu masyarakat yang demokratis"

4. UUD 1945 pasca Perubahan, melalui Pasal $28 \mathrm{~J}$ nampaknya melanjutkan paham konstitusi (konstitusionalisme) yang dianut oleh konstitusi Indonesia sebelumnya, yakni melakukan pembatasan tentang hak asasi manusia sebagaimana telah diuraikan di atas.

Sejalan dengan pandangan konstitusionalisme Indonesia tentang HAM sebagaimana telah diuraikan di atas, ketika kemudian dikeluarkan Ketetapan MPR Nomor XVII/MPR/1998 Tentang Hak Asasi Manusia, yang kemudian dijabarkan lebih lanjut dalam UU HAM, kedua produk hukum ini tampak sebagai kelanjutan sekaligus penegasan bahwa pandangan konstitusionalisme Indonesia tidaklah berubah karena ternyata keduanya juga memuat pembatasan terhadap hak asasi manusia. Sebagai contoh yaitu adanya pembatasan mengenai hak untuk hidup (right to life):

1. Tap MPR Nomor XVII/MPR/1998 memuat "Pandangan dan Sikap Bangsa Terhadap Hak Asasi Manusia" yang bersumber dari ajaran, nilai moral universal, dan nilai luhur budaya bangsa, serta berdasarkan pada Pancasila dan UUD 1945. Dalam Pasal 1 Piagam Hak Asasi Manusia dimuat ketentuan tentang hak untuk hidup yang berbunyi, "Setiap orang berhak untuk hidup, mempertahankan hidup dan kehidupannya", namun dalam Pasal 36-nya juga dimuat pembatasan terhadap hak asasi manusia termasuk hak untuk hidup sebagai berikut, "Di dalam menjalankan hak dan kebebasannya setiap orang wajib tunduk kepada pembatasan-pembatasan yang di- 
tetapkan oleh Undang-undang dangan maksud semata-mata untuk menjamin pengakuan serta penghormatan atas hak dan kebebasan orang lain, dan untuk memenuhi tuntutan yang adil sesuai dengan pertimbangan moral, keamanan, dan ketertiban umum dalam suatu masyarakat demokratis"

2. UU HAM dalam Pasal 9 ayat (1) dimuat ketentuan tentang hak untuk hidup dan dalam Pasal 4 ditentukan bahwa hak untuk hidup termasuk hak asasi manusia yang tidak dapat dikurangi dalam keadaan apapun dan oleh siapapun. Namun, Penjelasan Pasal 9 UU HAM menyatakan bahwa hak untuk hidup dapat dibatasi dalam dua hal, yaitu dalam hal aborsi untuk kepentingan hidup ibunya dan dalam hal pidana mati berdasarkan putusan pengadilan. Selain itu, Pasal 73 UU HAM juga memuat ketentuan mengenai pembatasan terhadap hak asasi manusia sebagai berikut, "Hak dan kebebasan yang diatur dalam undangundang ini hanya dapat dibatasi oleh dan berdasarkan undang-undang, semata-mata untuk menjamin pengakuan dan penghormatan terhadap hak asasi manusia serta kebebasan dasar orang lain, kesusilaan, ketertiban umum, dan kepentingan bangsa".

Dalam Pasal 28 I ayat (1) UUD 1945, terdapat sejumlah hak yang secara harfiah dirumuskan sebagai "hak yang tidak dapat dikurangi dalam keadaan apapun", termasuk di dalamnya hak untuk hidup dan hak untuk tidak dituntut berdasarkan hukum yang berlaku surut. Dalam konteks ini, dapat ditafsirkan bahwa Pasal 28 I ayat (1) haruslah dibaca bersama-sama dengan Pasal $28 \mathrm{~J}$ ayat (2), sehingga hak untuk tidak dituntut berdasarkan hukum yang berlaku surut tidaklah bersifat mutlak.

Oleh karena hak-hak yang diatur dalam Pasal $28 \mathrm{~J}$ ayat (1) UUD 1945 yaitu yang termasuk dalam rumusan " hak yang tidak dapat dikurangidalam keadaan apapun" dapat dibatasi, maka secara prima facie berbagai ketentuan hak asasi manusia diluar dari pasal tersebut, seperti misalnya kebebasan beragama (Pasal $28 \mathrm{E}$ ), hak untuk berkomunikasi (Pasal 28 F), ataupun hak atas harta benda (Pasal 28 G)sudah pasti dapat pula dibatasi, dengan catatan sepanjang hal tersebut sesuai dengan pembatasan-pembatasan yang telah ditetapkan oleh undang-undang.

Ketentuan HAM dalam UUD 1945 yang menjadi basic law adalah norma tertinggi yang harus dipatuhi oleh negara. Karena letaknya dalam konstitusi, maka ketentuan-ketentuan mengenai HAM harus dihormati dan dijamin pelaksanaannya oleh negara. ${ }^{7}$ Karena itulah Pasal 28 I ayat (4) UUD 1945 menegaskan bahwa perlindungan, pemajuan, penegakkan, dan pemenuhan HAM adalah tanggung jawab negara terutama pemerintah.

Walaupun telah ada Undang-Undang Nomor 39 Tahun 1999 Tentang HAM yang didasari oleh TAP MPR No. XVII Tahun 1998, namun dimasukkannya HAM ke dalam konstitusi diharapkan akan semakin memperkuat komitmen untuk pemajuan dan perlindungan HAMdi Indonesia, karena akan menjadikannya sebagai hak yang dilindungi secara konstitusional. Pesan ini kemudian ditangkap oleh Panitia Ad Hoc (PAH) I dan direkomendasikan kepada Sidang Tahunan MPR Tahun 2000 agar dimasukkan ke dalam Amandemen ke-2 UUD 1945. Pasal-Pasal tentang HAM dimasukkan ke dalam Bab X A dari Pasal 28 A sampai dengan Pasal $28 \mathrm{~J}$. Walaupun pencantuman pasal-pasal tersebut dinilai positif dari berbagai segi, namun dalam beberapa hal perlu dikritisi karena dianggap mengandung kelemahan baik dari segi perumusan, struktur, dan sistematikanya. Misalnya, pengelompokkan hak-hak tidak beraturan yang pada gilirannya menunjukkan bahwa para perumus kurang memahami jenis dan pengelompokkan HAM yang lazim dalam instrumen hukum HAM internasional. Dari segi substansinya tampak

\footnotetext{
7 Satya Arinanto, 2003, Hak Asasi Manusia Dalam Transisi Politik Indonesia, Jakarta: FH-Ul, hlm.17. Lihat juga T. Mulya Lubis, 1993, Hak-Hak Asasi Manusia Dalam Masyarakat Dunia: Isu dan Tindakan, Jakarta: Yayasan Obor Indonesia, hlm. 14
} 
kental dengan nuansa politis sehingga dapat mengurangi makna dari HAM itu sendiri.

Beberapa ahli hukum bahkan berpendapat bahwa Pasal 28 I Perubahan Kedua ini merupakan constitutional constraint (hambatan konstitusional) bagi penegakkan HAM di Indonesia. Hal ini ditandai dengan tidak diakuinya asas hukum berlaku surut bagi pelanggaran berat terhadap HAM yang digolongkan ke dalam kejahatan terhadap kemanusiaan. ${ }^{8}$ Namun, di pihak lain terdapat pendapat bahwa Pasal 28I tersebut dapat diterobos melalui Pasal 28J. Ketentuan dalam Pasal $28 \mathrm{~J}$ tidak dapat digunakan karena pada dasarnya pembentuk pasal ini menderogasi (mengingkari) ketentuan yang dibuatnya sendiri.

Pengaturan hak asasi manusia di Indonesia berdasarkan Undang-Undang Dasar 1945, yang menegaskan bahwa untuk menegakkan dan melindungi hak asasi manusia sesuai dengan prinsip negara hukum yang demokratis, maka pelaksanaan hak asasi manusia dijamin, diatur dan dituangkan dalam peraturan perundang-undangan, adalah dengan menetapkan Undang-Undang Nomor 39 Tahun 1999 Tentang Hak Asasi Manusia (meskipun dibentuk sebelum amandemen terhadap Pasal 28 Undang-Undang Dasar 1945).

Undang-Undang Nomor 39 Tahun 1999 Tentang Hak Asasi Manusia yang diundangkan pada tanggal 23 September 1999 dipandang sebagai salah satu peraturan pelaksana dari Ketetapan MPR Nomor XVII/MPR/1998 Tentang Hak Asasi Manusia, hal ini terlihat dalam salah satu dasar hukumnya yang mencantumkan ketetapan tersebut.

Pada saat Undang-Undang Nomor 39 Tahun 1999 ini sedang didiskusikan terdapat beberapa pendapat yang terbagi dalam dua ketegori besar, yakni pendapat yang menyatakan bahwa pada dasarnya ketentuan mengenai HAM tersebar dalam berbagai undang-undang, dan oleh karena itu tidak perlu dibuat satu undang-undng khusus tentang HAM. Pendapat

8 Sumali, 2003, Reduksi Kekuasaan Eksekutif di Bidang Peraturan Pengganti Undang-Undang, Malang: Universitas Muhammadiyah Malang, hlm.24. lain menyatakan bahwa pembentukan undangundang materi khusus tentang HAM perlu dilakukan mengingat Ketetapan MPR tidak berlaku operasional dan berbagai undangundang yang ada belum seluruhnya menampung materi HAM. Selain itu, undang-undang tersebut akan berfungsi sebagai undang-undang payung (umbrella act) terhadap peraturan perundang-undangan di bidang HAM yang sudah ada selama ini.

Dari sudut ilmu perundang-undangan, kritik terhadap Undang-undang Nomor 39 Tahun 1999 ini mencakup antara lain: ${ }^{9}$

1. Terdapat ketentuan yang tidak memuat norma atau kaidah, dan hal ini ditunjukkan dengan adanya Bab mengenai asas-asas dasar. Asas-asas dasar pada prinsipnya bukan merupakan kaidah atau norma hukum. Jadi, asas tidak perlu secara eksplisit dimuat dalam undang-undang melainkan akan menjiwai pasal-pasal yang ada dalam UU bersangkutan.

2. Penyimpangan terhadap asas bahwa hukum tidak berlaku surut seharusnya tidak diletakkan pada bagian Penjelasan, melainkan pada bagian Batang Tubuh UU. Hal ini disebabkan Penjelasan tidak memuat norma atau kaidah. Atau dengan kata lain, Penjelasan tidak berfungsi untuk menciptakan kaidah hukum.

Berkaitan dengan substansi atau materi yang diatur, pengelompokkan HAM terdiri atas hak untuk hidup, hak berkeluarga dan melanjutkan keturunan, hak mengembangkan diri, hak memperoleh keadilan, hak atas kebebasan pribadi, hak atas rasa aman, hak atas kesejahteraan, hak turut serta dalam pemerintahan, hak wanita, dan hak anak. Sama halnya dengan Ketetapan MPR Nomor XVII/MPR/1998, UndangUndang Nomor 39 Tahun 1999 tidak secara tegas menyatakan alasan kategorisasi HAM. Pada bagian Penjelasan hanya disebutkan bahwa penyusunan Undang-undang Nomor 39 Tahun 1999 berpedoman pada Konvensi PBB Tentang Penghapusan Segala Bentuk Diskriminasi ter-

\footnotetext{
${ }^{9}$ Ibid, hlm. 90
} 
hadap wanita, Konvensi PBB tentang hak-hak anak, serta berbagai instrumen hukum internasional lainnya yang mengatur tentang HAM. Meskipun tidak dikelompokkan secara tegas, pada dasarnya materi HAM telah mencakup HAM di bidang sipil, politik, ekonomi, sosial dan budaya.

Masih berkaitan dengan substansi undangundang, tampaknya Undang-Undang Nomor 39 Tahun 1999 ini membaurkan asas-asas dasar dengan ketentuan mengenai HAM itu sendiri. Apabila diteliti lebih lanjut, pasal-pasal yang memuat asas-asas dasar justru mengatur HAM, isalnya Pasal 4 yang mengatur tentang hak-hak yang bersifat non-derogable, hak setiap orang untuk diakui sebagai pribadi di bidang hukum yang berhak untuk mendapat bantuan dan perlindungan yang adil dari pengadilan yang objektif dan tidak berpihak (Pasal 5 ayat (1) dan (2), Pasal 5 ayat (3) yang mengharuskan adanya perlindungan HAM yang lebih terhadap kelompok yang rentan. Namun, satu hal yang perlu dihargai dari Undang-Undang Nomor 39 Tahun 1999 ini adalah penempatan pengatiran mengenai HAM anak dan HAM wanita yang dilakukan secara terpisah. Penempatan ini tampaknya sejalan dengan perkembangan yang terjadi di dunia internasional, yang dibuktikan dengan adanya instrumen hukum internasional yang terpisah bagi anak dan wanita.

\section{E. Penutup}

1. Simpulan

b. Pengaturan tentang hak asasi manusia sebelum amandemen UUD 1945 diatur sebagai hak dan kewajiban warga negara Republik Indonesia yang di dalamnya terkandung nilai-nilai hak asasi manusia dan diatur dalam Pasal 27 sampai dengan Pasal 34.

c. Pengaturan hak asasi manusia setelah amandemen Undang-Undang Dasar 1945 mengalami perubahan, yaitu diatur dalam Pasal 28 A sampai dengan Pasal $28 \mathrm{~J}$.

d. Pengaturan tentang hak asasi manusia berdasarkan Undang-Undang Nomor 39
Tahun 1999 Tentang Hak Asasi mencakup hak-hak sebagai berikut :

1) Hak untuk hidup;

2) Hak berkeluarga dan melanjutkan keturunan;

3) Hak mengembangkan diri;

4) Hak memperoleh keadilan;

5) Hak atas kebebasan pribadi;

6) Hak atas rasa aman;

7) Hak atas kesejahteraan;

8) Hak turut serta dalam pemerintahan;

9) Hak wanita;

10) Hak anak.

\section{Saran}

Pengaturan tentang hak asasi manusia setelah amandemen UUD 1945 diatur secara rinci dalam Pasal 28 A sampai dengan $28 \mathrm{~J}$. Berdasarkan ketentuan tersebut, bahwasannya tidak ada satupun hak asasi manusia di Indonesia yang bersifat mutlak dan tanpa batas,. Hak asasi manusia bukanlah hak yang absolute. dalam pelaksanaannya dibatasi oleh hak orang lain, moral, keamanan, dan ketertiban. Oleh karena itu, dalam hak asasi manusia dikenal juga adanya kewajiban dasar mnusia. Dengan demikian, pelaksanaan hak asasi seseorang dan segenap elemen masyarakat hendaknya dapat menghormati hak asasi orang lain, sebagimana telah diatur dalam UUD 1945.

\section{Daftar Pustaka \\ Buku}

Arinanto, Satya. 2003. Hak Asasi Manusia Dalam Transisi Politik Indonesia, Jakarta: FH-UI;

Asshiddiqie, Jimly. 2005. Konstitusi dan Konstitusionalisme Indonesia. Jakarta: Konstitusi Press;

Bahar, Safroedin. 1996. Hak Asasi Manusia, Analisis Komnas HAM dan Jajaran Hankam/ABRI. Jakarta: Pustaka Sinar Harapan;

Budiardjo, Miriam. 1980. Dasar-Dasar Ilmu Politik. Jakarta: Gramedia;

Effendi, Masyhur. 1994. Haka Asasi Manusia dalam Hukum Nasional dan Internasional. Jakarta: Ghalia Indonesia 
144 Jurnal Dinamika Hukum

Vol. 8 No. 2 Mei 2008

Fadjar, Mukthi, 2004, Tipe Negara Hukum, Malang: Bayumedia Publishing

Lubis, T. Mulya. 1993. Hak-Hak Asasi Manusia Dalam Masyarakat Dunia: Isu dan Tindakan. Jakarta: Yayasan Obor Indonesia;

Manan, Bagir. 2001. Perkembangan Pemikiran dan Pengaturan Hak Asasi Manusia di Indonesia. Bandung: Alumni;

Sumali. 2003. Reduksi Kekuasaan Eksekutif di Bidang Peraturan Pengganti UndangUndang. Malang: Universitas Muhammadiyah Malang;

Wahjono, Padmo. 1983. Indonesia Negara Berdasar Hukum. Jakarta: Ghalia Indonesia;

\section{Peraturan Perundang-undangan}

Undang-Undang Dasar Negara Republik Indonesia 1945;

Undang-Undang Nomor 39 Tahun 1999 tentang Hak Asasi Manusia. 